\title{
Ectopic Prostate Originating from the Anterior Bladder Wall
}

\author{
Mesane Ön Duvarı Kaynaklı Ektopik Prostat
}

\author{
Sıtkı Ün'1, Ahmet Selçuk Dindar', Osman Köse' ${ }^{1}$, Alper Cihat Erdal', Fulya Çakalağaoğlu Ünal' ${ }^{2}$ Yüksel Yılmaz' \\ 'İzmir Katip Çelebi University, Atatürk Training and Research Hospital, Clinic of Urology, Izmir, Turkiye \\ ${ }^{2}$ Izmir Katip Çelebi University, Atatürk Training and Research Hospital, Clinic of Pathology, Izmir, Turkiye
}

\begin{abstract}
Ectopic prostate in the urinary bladder is quite rare. The presenting complaint may vary according to the location of the prostate tissue in the bladder. Patients usually present with hematuria, dysuria, bladder neck obstruction, kidney failure, and urinary tract infections. In this paper, we present a case of ectopic prostate arising from the anterior bladder wall.
\end{abstract}

Keywords: Ectopic prostate, bladder front wall, embryology

Öz

Mesane içinde prostat ektopisi nadir rastlanan bir durumdur. Başvuru nedenleri ektopik prostat dokusunun mesane içindeki yerine göre değişebilir. Genellikle hematüri, dizüri, mesane çııım obstrüksiyonu, böbrek yetmezliği ve üriner sistem enfeksiyonu ile prezente olurlar. Biz bu çalışmada mesane ön duvarı kaynaklı ektopik prostat olgusunu sunuyoruz.

Anahtar Kelimeler: Ektopik prostat, mesane ön duvar, embriyoloji

\section{Introduction}

"Ectopia" or "Ectopy" refers to congenital displacement or abnormal positioning of an organ or body part. Ectopic prostate is a rare condition. The most common place for ectopic prostate has been reported to be posterior urethra (1). In the literature, there are other reported sites such as sacrum, bladder, uterus, cervix, vagina, testicles, seminal vesicles and retrovesical area $(2,3,4,5,6)$.

In this paper, we present a case of ectopic prostate arising from the anterior bladder wall.

\section{Case Presentation}

A 75-year-old male patient presented to our clinic with the complaint of macroscopic hematuria for the past 3 days. Physical examination was unremarkable. Digital rectal examination revealed grade 1 benign prostatic hyperplasia. Liver and kidney function tests were normal. Total prostate-specific antigen (PSA) level was $2 \mathrm{ng} / \mathrm{dL}$.
Ultrasonography showed bladder wall thickening.

Abdominal computed tomography depicted advanced bladder wall thickening and soft tissue density which produced masslike images (Figure 1).

The patient underwent cystoscopy under local anesthesia with an initial diagnosis of bladder tumor.

Two wide-based, polypoid, solid and hyperemic masses were resected from the anterior bladder wall. The bigger mass had a diameter of $3 \mathrm{~cm}$.

Immunohistochemical examination showed prostatic-type polyp and ectopic prostate tissue (Figure 2).

The patient was given detailed approval for use in scientific publication.

\section{Discussion}

The generally accepted opinion on the mechanism of ectopia in the medicine community is that it is a congenital condition

Correspondence: Sıtkı Ün MD, İzmir Katip Çelebi University, Atatürk Training and Research Hospital, Clinic of Urology, İzmir, Turkiye Phone: +90 2322434343 E-mail: sitki@doctor.com ORCID-ID: orcid.org/0000-0003-1477-7497

Received: 13.03.2016 Accepted: 22.09.2016

Cite this article as: Ün S, Dindar AS, Köse O, Erdal AC, Çakalağaoğlu Ünal F, Yılmaz Y. Ectopic Prostate Originating from the Anterior Bladder Wall. J Urol Surg 2017:4:143-144.

${ }^{\circ}$ Copyright 2017 by the Association of Urological Surgery / Journal of Urological Surgery published by Galenos Publishing House. 


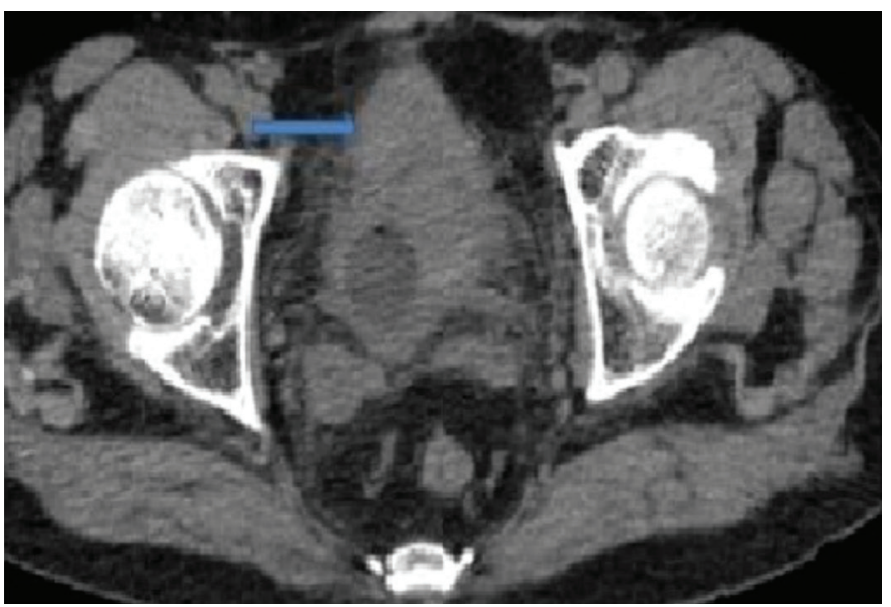

Figure 1. Ectopic prostate originating from front wall of the bladderradiological view

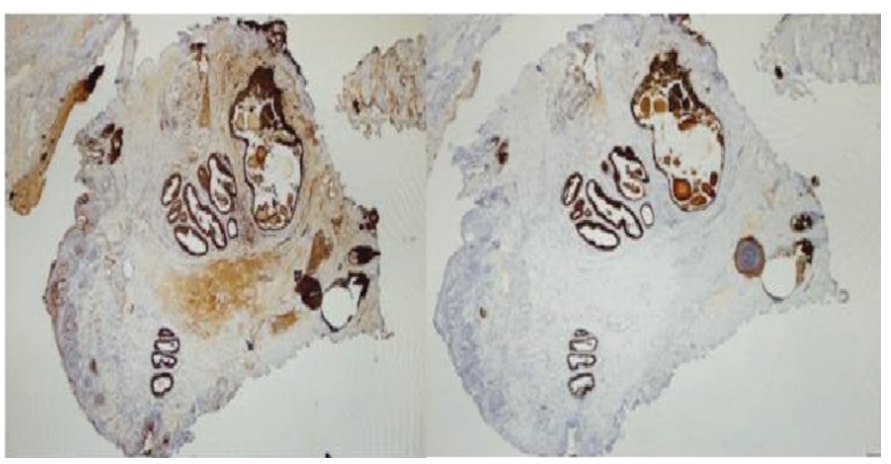

Figure 2. Ectopic prostate originating from front wall of the bladderhistopatological view

which develops during embryonic development stage. The bladder and urethra are derived from the primitive urogenital sinus. This formation continues with the prostate in the $3^{\text {rd }}$ month. Abnormal migration of prostate cells with differentiation abilities can cause ectopia in rare cases (1).

The definite diagnosis is made following histopathological examination of the mass. Prostatic glands are stained easily using prostate acid-phosphatase and PSA (2).

Ectopic prostate within the bladder is quite rare (4).

The main complaint can be various due to different placement of the prostate tissue within the bladder. The patients usually present with hematuria, dysuria, bladder neck obstruction, kidney failure and urinary tract infections (2).
The masses within the bladder can be seen either as a flat or polypoid structure. Flat masses are usually observed around the bladder neck whereas polypoid masses are mainly located on the bladder wall (7).

Although there is a reported case of malignant transformation in the literature, recurrence following surgery has not been reported (1).

\section{Ethics}

Informed Consent: Consent form was filled out by the participant.

Peer-review: Externally peer-reviewed.

\section{Authorship Contributions}

Surgical and Medical Practices: S.Ü., A.S.D., Concept: S.Ü., A.S.D., Design: S.Ü., O.K., Data Collection or Processing: S.Ü., A.C.E., Analysis or Interpretation: S.Ü., F.Ç.Ü., Literature Search: S.Ü., Y.Y., Writing: S.Ü.

Conflict of Interest: No conflict of interest was declared by the authors.

Financial Disclosure: The authors declared that this study received no financial support.

\section{References}

1. Bellezza $G$, Sidoni $A$, Cavaliere A. Ectopic prostatic tissue in the bladder. Int J Urol 2005;12:1066-1068.

2. Eren $F$, Güzelsoy $M$, Eren $B$, Aydın 0 . Ectopic prostate presenting as a mass in bladder. Indian J Urol 2008;24:564-565.

3. Fulton RS, Rouse RV, Ranheim EA. Ectopic prostate: case report of a presacral mass presenting with obstructive symptoms. Arch Pathol Lab Med 2001;125:286-288.

4. Dogra PN, Ansari MS, Khaitan A, Safaya R, Rifat. Ectopic prostate: an unusual bladder tumor. Int Urol Nephrol 2002;34:525-526.

5. McCluggage WG, Ganesan R, Hirschowitz L, Miller K, Rollason TP. Ectopic prostatic tissue in the uterine cervix and vagina: report of a series with a detailed immunohistochemical analysis. Am J Surg Pathol 2006;30:209215.

6. Tan FQ, Xu X, Shen BH, Qin J, Sun K, You O, Shang DS, Zheng XY. An unusual case of retrovesical ectopic prostate tissue accompanied by primary prostate cancer. World J Surg Oncol 2012;10:186.

7. Delladetsima J, Theodorou C, Dapolla Y, Dimopoulos C. Prostatic-type epithelium in urinary bladder. Clinical, histologic, and immunohistochemical study. Urology 1990;36:445-448. 